\title{
Determinants of Equity in Access to Senior High School Education in the Ghanaian Education System
}

\author{
Paul Dela Ahiatrogah \\ Centre for Continuing Education, \\ University of Cape Coast, Cape Coast, Ghana. \\ Tel: 2330243106249 Email :pauldela57@yahoo.com. \\ Brandford Bervell \\ Centre for Continuing Education, \\ University of Cape Coast, Cape Coast, Ghana. \\ Tel: 2330545033742 Email: b_brandford@yahoo.co.uk.
}

\section{Doi:10.5901/jesr.2013.v3n2p273}

\begin{abstract}
This study explores equity in the provision of secondary education to public and private junior high school products in Ghana. The purpose of the study was to document the role that gender, programme offered performance score, type of JHS attended, and governing authority of schools play in the seeming inequity in the selection process. The key findings showed that there is a statistically significant difference between public and private JHS graduates in terms of gaining access to SHS. However, the difference was not gender based. It was also found that the level of access to SHS opened to JHS graduates differ according to whether the school is a single sex or mixed sex institution and also the choice of programme. Finally, the study indicated that there is no statistically significant difference between well endowed and less endowed SHS in terms of gaining admission into them. It is, therefore, recommended that efforts directed towards bridging the equity gap should be vigorously pursued.
\end{abstract}

Keywords: Equity, Access, Gender, Programme of study, Well and Less Endowed SHS.

\section{Introduction}

It is the wish of most parents in Ghana that their wards obtain high school education. However, for some time now, getting admission into Senior High School (SHS) and other tertiary institutions in Ghana has become a serious problem. Annually, after the release of Junior High School (JHS) results, parents move from school to school in search of admission for their wards. Many of them go through a lot of frustration and immeasurable anger on annual basis due to this problem. Some parents are compelled to use "ways and means" to enable them secure admission. According to Osei-Mensah (2011), as at now, there are three classes of SHSs in Ghana. These are: the "Clarendon" schools, most of them established by the faith-based churches during the colonial days; the Ghana Education Trust Schools, established in the 1960s during Kwame Nkrumah's regime; and Community Rural Schools most of them established after 1987. Most parents prefer that their wards gain admission to the well-endowed schools in the first category.

In 2004, the government felt the need to alleviate the disparity in SHS admissions by introducing the Computerized School Selection and Placement System (CSSPS) for SHS. This system is based on the performance of students in the Basic Education Certificate Examination (BECE). A very good grade is required to gain admission into a SHS in Ghana because of the limited number of places available to the teaming JHS graduates that are turned out every year. However, because of the wide disparities in the status of SHS in terms of their performance and public image, admission to the schools have become very competitive paving the way for some people to manipulate the processes. 
Some misgivings have been expressed about the present system to the extent that people are calling for a review of the system. For instance, some old students associations are calling for $10 \%$ allocation of placement because of their role in the development of their schools. Similarly, the Central Regional minister was reported to have threatened that if a quota of school placement of SHS in Cape Coast was not given to the region, they will close down the schools because the natives of Cape Coast were not having access to the best schools in the region. The National Association of Graduate Teachers (NAGRAT) has also called for investigations into the operations of the CSSPS to instill sanity and to ensure that children are selected and placed purely on merit (Daily Graphic, Monday, November 14, 2011 pg. 20). On their part, the Catholic Bishops Conference in a communiqué has called on government to abolish the CSSPS for there appears to be as much, if not more corruption, confusion, and inefficiency in this system as compared to the former system. On the other hand, the Ghana Education Service (GES) says it will not scrap the CSSPS because of the overwhelming support the system has received from the public. All the concerns raised seem to centre on the selection and placement procedures.

In an attempt to ensure a certain measure of equity, the government has directed that $30 \%$ of admissions of every SHS be reserved for candidates within a certain radius of the schools. This directive has brought in its wake several challenges and complications resulting in dissatisfaction among parents and pupils to the extent that a committee has been set up to investigate issues relating to the CSSPS. This state of affairs brings into sharp focus the issue of equity in access to secondary education in the developing world in general and Ghana in particular.

\section{2 Literature Review}

Philosophically, selection of pupils into schools is based on the performance of the particular school, its aims and objectives, the course the school has got to offer and the end product the institution wants to have at the end of the day. Broomer (1999) opined that sometimes a lottery is the fairest way of selecting and distributing a good in a system where competition is at play. In line with this argument, some others have suggested that selection should be based on tossing a coin. On the other hand, Hooker (2009) thinks that it is not clear what fairness is required in these two scenarios. To him, therefore, selection of pupils into schools may not have one way in every school but will be based on the objectives and aims of the school.

Another school of thought has it that placement is determined solely on the basis of whether a score is above or below a certain cut off point that is used to determine passing or failing grades. For the majority of students at community colleges, the consequences of assessment are placement into development education where more than half of the students are assigned to remediation but never a move from bottom to the top (Bailey, Jeong and Cho, 2010). According to Bailey (2009), placement of students into schools solely depends on the performance of the student. In effect, student performance standards are explicit definitions of what the student must do to demonstrate proficiency at a specific level on the content standards (National Centre for Research on Evaluation, Standards and Students Testing, 1999). Supporting this position, Marzaro and Kendall (1996) stated that a performance standard decides a specific use of knowledge and skills; it is not a description of knowledge, but a description of some application.

The Dakar Framework for Action (2000) set out goals that are relevant to and have implications for secondary education particularly in ensuring that learning needs of all young people and adults are met through equitable access and appropriate learning and life skills programmes. It was also aimed at eliminating gender disparities in primary and secondary education by 2005 and achieving gender equality in education by 2015, with a focus on ensuring girls' full and equal access to and achievement in basic education of good quality.

According to Ndong-Jatta (2006), issues such as enrolment, quality imperatives, literacy, numeracy, gender disparities, investments and returns on expenditure of secondary education need to be closely examined. Provision of quality secondary education relevant to the changing needs of young people and the society at large is a growing concern world wide even for those countries with universal coverage. As efforts to increase the participation rates of young people in post-primary education step up, there is the need to expand school facilities or introduce the shift system to match the demand for places in the institutions. There is the need to avoid less inclusive policy measures of continued selective processes, early tracking/streaming at the end of primary education. 
Many African countries, unfortunately, are unable to meet the increasing demand for secondary education due to their inability to build on the successes of the universal primary education system some time ago. For decades, the sub-sector of secondary education has been neglected in Africa both by the governments and donor agencies. The apparent neglect of this sub-sector has resulted in limited access, especially for young women and rural communities, poor quality of curriculum and lack of qualified teachers and essential infrastructure.

Historically, secondary education is more accessible to urban areas than to rural communities in Africa (Boaduo, 2005). Additionally, there are some significant gender disparities in the distribution of secondary education in Africa. Socio-cultural, religious, and economic factors have contributed to this disparity that has placed young women at a serious disadvantage (Bregman \& Bryner, 2003). In African countries, more boys (28 percent) benefit from secondary education than girls (22 percent) do. (The World Bank, 2005), yet secondary education plays a vital role in the political and socio-economic development of Africa

The crisis facing human resource development in Africa is clearly manifested in the secondary education sub-sector in the forms of limited access to secondary education and poor quality of the education provided. The World Bank (2005) report describes secondary education as the crucial link between primary schooling, tertiary education, and the labor market. The report notes further that the task confronting education policymakers in Africa is to transform secondary education institutions and current schooling practices to align them with the fast growing demands of globalization and the technology-driven world. That is, the main focus of the education policy process in Africa is to address the twin challenges of increasing access to, and improving quality and relevance of secondary education for all young people in the region. This underscores the imperative to transform teaching and learning in primary and secondary schools in African countries.

Roemer (1995; 1998) argued that justice requires leveling the playing field by rendering everyone opportunities equal in an appropriate sense; and letting individual choices and their effects dictate further outcomes. In Ghana, getting equal access to secondary school is a problem since the number of pupils out of JHS triples the intake of the SHS. This makes it difficult to have equal access to SHS. Asare (2010) suggests that to break the jinx and to improve equal access to SHS, the government should provide more "day" SHS in major towns at the district level to enhance the access to SHS

Many studies point to the fact that public school students receive higher grades in colleges than private school students (Lathrop \& Kieffer, 1959; McAthur, 1954; and Seltzer, 1948). One hypothesis is that public school students do better in colleges because they are more rigorously selected for admission. On the other hand, Hoffer (1998) found that pupils in USA catholic schools have higher educational outcomes than pupils in public schools irrespective of their social background. Similarly, Dronkers and Hemsing (1999) reported that German private schools had higher grades than public schools after controlling for other characteristics.

\subsection{Theoretical Framework}

The study is underpinned by Adams' (1963) Equity Theory which states that the presence of inequity will motivate a person to achieve equity or reduce inequity, and the strength of motivation to do so will vary directly with the amount of inequity. The Equity theory posits that if the person perceives that there is inequality, where either their output/input ratio is less than or greater than what they perceive as the output/input ratio of the other person in the relationship, then the person is likely to be distressed. Educational equity is defined on three levels: equality, justified inequality, and fair process (Boocock, Sarane Spence, Predow, Karen, 1979). The Equity theory is also called Inequity Theory as it is the unequal difference that is often the area of interest. Current data indicate that despite expansion in access to learning opportunities in most countries, educational equity has proved highly elusive (OECD, 2001a, p. 73). According to Allen and White (2002), the lack of predictive ability of equity theory contributed to its 'falling out of favor' only to be revived by interest in organizational justice and equity ... spurred in part by an extension of the original Equity Theory to include individual differences and the equity sensitivity construct.

Rothstein (2004) noted that no society can realistically expect schools alone to abolish inequality. The assertion is that if students come to school in unequal circumstances, they will largely, though not entirely, leave schools with unequal skills and abilities, in both cognitive and non-cognitive domains. This does not in any way provide sufficient grounds for educators to throw up their hands in desperation because all is not yet lost. 


\subsection{Statement of the Problem}

Since CSSPS replaced the manual system of selection and placement into SHSs, about seven years ago, it has been beset with many challenges. In 2010, out of the total of 350,888 candidates who wrote the BECE, only 172 , 359 (49.12\%) passed from 10,016 public and private JHSs, In 2011, out of the 177,000 vacancies declared by heads of SHSs and TIs, only 176,128 candidates met the criteria for selection and placement. However, some 52 SHSs were over-subscribed by candidates. For instance, while 300 vacancies were declared at Wesley Girls' High School in Cape Coast, 12,400 qualified candidates had selected the school as their first choice. Thus, the wellendowed SHSs are every year over-subscribed. It appears the doors to the well-endowed SHSs are virtually closed to pupils from certain social and economic background. Furthermore, it is not known whether gender, type of SHS, governing authority, and programme of study have any influence on access to SHS in Ghana. The researchers, therefore, got curious and decided to conduct a research aimed at looking at how the system ensures equity in the access to SHS by products of public and private JHS products.

\subsection{Hypotheses}

The following hypotheses were formulated to guide the study:

1. Ho: There is no statistically significant difference between public and private JHS graduates in terms of gaining access to SHS in Ghana

2. Ho: There is no statistically significant difference between male and female JHS graduates in terms of gaining access to SHS in Ghana

3. Ho: There is no statistically significant difference between well endowed and less endowed SHS in terms of JHS graduates gaining access to them

4. Ho: There is no statistically significant impact of type of SHS on JHS graduates gaining access to secondary education in Ghana

5. Ho: There is no statistically significant influence of programme selected and JHS graduates gaining access to SHS in Ghana

6. Ho: The governing authority of a SHS plays no statistically significant role in JHS graduates gaining access to SHS in Ghana

\section{Methodology}

\subsection{Design}

To meet the aim of the study, Nunan's (1992) quantitative ethnographic design was used. The quantitative aspect of this study has to do with data collected from the admission list generated from the Computer School Selection and Placement System (CSSPS). Some of such data were: gender, programme offered, performance score, and type of JHS attended. The study meets Nunan's requirements because no variable of interest was manipulated. Besides, an interpretative analysis of the data was done and an interaction was established between hypotheses and data collection (Madu, 2010)

\subsection{Population and Sample}

The target population for the study was all prospective fresh students placed in all Senior High Schools in the Ashanti region. The accessible population, however, was drawn from four well endowed and two less endowed SHS in the region. Purposive sampling technique was adopted in the selection of Prempeh College, T.I. Ahmadiyya SHS, Kumasi Girls SHS and Kumasi Anglican SHS which are all well endowed schools and reflecting unisex, mixed sex, mission school and government controlled schools. The less endowed schools used were Achinakrom SHS and Jachie-Pramso SHS.

Out of the 2,808 candidates used for the study, 2,186 were drawn from well endowed SHS while the rest 622 were from less endowed schools. One thousand two hundred and twenty seven (1227) were purposively chosen from government owned SHS while 1,073 were from Christian mission controlled schools. The rest 508 
represented Muslim mission schools. With regards to status of school, 622 candidates came from day only institutions while the remaining 2186 were from day and boarding schools. Similarly, 553 and 605 of the candidates were drawn from boys and girls schools respectively while the rest 1650 came from mixed sex schools. Six programmes of study were covered in this research. They were: Business (755), Science (512), General Arts (892), and Visual Arts (310). The rest are: Agriculture (146) and Home Economics (193). In terms of gender, 1,676 and 1,132 boys and girls were studied respectively. On the whole, 1,128 candidates came from public while the remaining 1,680 were drawn from private Junior High Schools.

\subsection{Data Collection Procedure}

The researcher visited the schools and discussed the purpose of the study with the Headmasters/mistresses and obtained permission to carry out the research. The Headmasters/mistresses in turn assigned the Assistant Headmaster (Academic) to assist with the necessary information needed. In two cases, the Assistant Headmaster/mistresses agreed and released the documents on the same day. In the other schools, different dates were negotiated for the researcher to come back for the data. The data collection lasted for thirteen working days from $28^{\text {th }}$ October to $15^{\text {th }}$ November, 2010. On the average, two days was spent in each school.

\section{Results and Discussion}

\subsection{Hypothesis One}

The analysis in Table 1 shows the results of hypothesis one which sought to establish whether there is a statistically significant difference between public and private JHS graduates in terms of gaining access to SHS at alpha $(\alpha)$ value of 0.05 .

Table 1: Results of t-test on category of JHS and access to SHS

\begin{tabular}{|rr|c|c|c|c|c|}
\hline \multicolumn{2}{|c|}{ Category of school } & $\mathrm{N}$ & Mean & Std. Deviation & df & Sig \\
\hline Score obtained by candidate & Public & 1128 & 3.1223 & .84836 & 2806 & .004 \\
& Private & 1680 & 3.5952 & .76584 & & \\
\hline
\end{tabular}

The independent t-test was statistically significant, $t(2806)=.004, p>.05$. The results demonstrate that there is statistically significant difference between public and private JHS graduates in terms of gaining access to SHS. The results shown in Table 1 also revealed that access to SHS is higher for private JHS products than public JHS products $(3.1223<3.5952)$. The null hypothesis is therefore rejected.

This finding goes to support Dronkers and Hemsing's (1999) study which established that German private schools had higher grades than public schools because admissions to SHS in Ghana are based solely on academic performance. This is also confirmed by the ranking of JHS in 2006 and 2007 which showed that the private schools in Ghana are better than the public schools because the private schools took the first twenty places and dominated in the first hundred by $70 \%$. Every year, the ranking of BECE results by the regional and district education offices also indicate a clear cut of how the private schools dominated the public schools in all corners.

\subsection{Hypothesis Two}

Hypothesis 2 examined whether JHS graduates admission into SHS has any gender implications. The results of this analysis is showed in Table 2. 
Table 2: Results of t-test on gender and access to SHS

\begin{tabular}{|cc|c|c|c|c|c|}
\hline & Gender of candidate & $\mathrm{N}$ & Mean & Std. Deviation & df & \multicolumn{1}{c|}{ Sig } \\
\hline \multirow{2}{*}{ Category of school } & Male & 1676 & 1.6050 & .48899 & 2806 & .083 \\
& Female & 1132 & 1.5883 & .49235 & & \\
\hline
\end{tabular}

The analysis shown in Table 2 reveals that even though more males than females gain access to SHS $(1.6050>1.5883)$ the difference between male and female JHS graduates offered admission was not statistically significant, $t(2806)=.083, p>.05$. The null hypothesis is, therefore, accepted.

This finding negates the general perception that girls do not have equal access to education and which has been confirmed that in Africa, more boys than girls benefit from secondary education.(The World Bank, 2005). According to UNICEF (2008), the gender equality equation is a powerful one. By combining the right to education with rights within education, we can achieve rights through education. Indeed, gender equality is an essential strategy for ending discrimination and achieving justice in societies. But beyond merely having equal access to education, true gender equality means that schools are gender-sensitive environments that promote equal participation and empowerment.

Gender equality requires adapting equally to the needs and interests of girls and boys, creating a school environment that is friendly to both sexes and ensuring that women are equally represented in teaching, administrative and educational leadership roles.

\subsection{Hypothesis Three}

It was hypothesized that there is no statistically significant difference between well endowed and less endowed SHS in terms of JHS graduates gaining admission into them. The result of the analysis is shown in Table 3.

Table 3: Results of t-test on school category and access to SHS

\begin{tabular}{|ll|c|c|c|c|c|}
\hline & Category of School & $\mathrm{N}$ & Mean & Std. Deviation & $\mathrm{df}$ & Sig \\
\hline Category & ofWell Endowed School & 2186 & 1.6770 & .46772 & 2806 & .893 \\
school & Less Endowed & 622 & 1.3215 & .46744 & & \\
\hline
\end{tabular}

The data tabulated in Table 3 indicates that there is no statistically significant difference between well endowed and less endowed SHS in terms of JHS graduates gaining admission into them, $t(2806)=.893, p>.05$. The result of this analysis therefore rejects the research hypothesis that there is a statistically significant difference between well endowed and less endowed SHS in terms of admission requirements.

This finding is quite revealing because the general notion in Ghana is that private school products get more access to well endowed SHS at the expense of public school products. It therefore falls in line with the USA Equal Access Act passed in 1984 which explained that it shall be unlawful for any public secondary school which receives federal financial assistance and which has a limited open form to discriminate against any student on the basis of the religious, political, philosophical or other content. Essentially, all schools must grant equal opportunity to all categories of students.

\subsection{Hypothesis Four}

Table 4 shows the results of the analysis of data along the lines of access to type of SHS (girls only, boys only and mixed schools) 
Table 4: Results of one way ANOVA on type of school and access to SHS

\begin{tabular}{|l|c|c|c|c|c|}
\hline & Sum of Squares & $\mathrm{df}$ & Mean Square & $\mathrm{F}$ & Sig. \\
\hline Between Groups & 15.995 & 2 & 7.998 & 34.048 & .000 \\
Within Groups & 658.876 & 2805 & .235 & & \\
Total & 674.872 & 2807 & & & \\
\hline
\end{tabular}

A one way ANOVA was conducted to determine the relationship between type of school and access to SHS, with the independent variable being type of school and the dependent variable category of JHS. The ANOVA was statistically significant, $F(2,2805)=.000, p>.05$. That is, the levels of access to SHS open to JHS graduates differ according to whether the school is a unisex or co-educational institution. An LSD post hoc test revealed that the direction of difference lied on all fronts except boys' only and girls' only institutions. Thus, the outcome of the analysis failed to accept the null hypothesis.

This finding complements the work of Asare (2010) who suggested that to break the jinx and to improve equal access to SHS, the government should provide more "day" SHS in major towns at the district level to enhance access to SHS. Even though research has revealed that many opponents of unisex schools have changed their minds and effectively opened the doors of all-male public schools to females, it has not in any way affected access to the institutions. It is now clear that advocates of this position do so purely in the name of promoting effective discipline in schools.

\subsection{Hypothesis Five}

The study also sought to establish whether programmes offered in the SHS significantly influence the selection of JHS graduates for admission. The result is shown in Table 5

Table 5: Results of one way ANOVA on programme admitted to and access to SHS

\begin{tabular}{|l|c|c|c|c|c|}
\hline Source of Variation & Sum of Squares & $\mathrm{df}$ & Mean Square & $\mathrm{F}$ & Sig. \\
\hline Between Groups & 26.594 & 5 & 5.319 & 22.989 & .000 \\
Within Groups & 648.278 & 2802 & .231 & & \\
Total & 674.872 & 2807 & & & \\
\hline
\end{tabular}

Again, one way ANOVA was used to examine the relationship between programmes offered to candidates and gaining admission to SHS. The independent variable was category of JHS while the dependent variable was programme applied for. The analysis portrayed in Table 5 indicates that the ANOVA was statistically significant $F$ $(5,2802)=.000, p>.05$. Multiple comparisons were therefore carried out using LSD post hoc tests which revealed that the Science programme differed from all other programmes in terms of access while General Arts, Agriculture, and Home Economics had one exception each. In the case of Business, Visual Arts, and General Arts programmes, the direction of difference was noted only in Science, Agriculture and Home Economics.

This finding runs counter to an earlier study by Karabel (2005) on admissions to Harvard, Yale, and Princeton. The study showed that these schools chose to give up on pure academic performance as standards for admission and instead focus on something more varied, ambiguous, and amorphous as "character." Karabel also found that the move away from academic standards to character was motivated by a deep anti-semitism.

\subsection{Hypothesis Six}

Finally, it was hypothesized that the governing authority of a SHS plays a significant role in JHS graduates gaining admission to SHS. The outcome of the analysis in respect of the data along that line is reflected in Table 6. 
Table 6: Results of one way ANOVA on governing authority and access to SHS

\begin{tabular}{|l|c|c|c|c|c|}
\hline Source of Variation & Sum of Squares & $\mathrm{df}$ & Mean Square & $\mathrm{F}$ & Sig. \\
\hline Between Groups & 18.865 & 2 & 9.433 & 40.333 & .000 \\
Within Groups & 656.007 & 2805 & .234 & & \\
Total & 674.872 & 2807 & & & \\
\hline
\end{tabular}

The analysis shown in Table 6 indicates that the ANOVA was statistically significant $F(2,2805)=.000, p>$ .05. A post hoc test was therefore executed using LSD. The direction of difference in the case of government controlled SHS was on both fronts of Christian and Muslim governed schools. However, both Christian mission schools and Muslim institutions showed direction of difference only in the case of government controlled SHS.

This finding supports the work of Hoffer (1998) who found that pupils in USA catholic schools had higher educational outcomes than pupils in public schools irrespective of their social background. Lewin (2007) reports that in most of Sub-Sahara Africa (SSA) the number of children admitted to secondary education is limited by the number of places available and the direct costs of participation to households, and not to the numbers who pass primary leaving examinations. Sometimes admission quotas such as geographic location, ethnic group, and gender are used. Non-government schools generally operate more flexible entrance criteria which are influenced by affiliation in faith based schools, and ability to pay fees in the for-profit private sector. Supply side constraints are most prominent in the lowest enrolment countries. It is obvious that as demand side constraints increase in importance, participation rates grow.

\section{Conclusion}

It is concluded that there is no equity between public and private JHS graduates in terms of gaining access to SHS because access to SHS is higher for private JHS products than public JHS products. Furthermore, it is clear that even though more males than females gain access to SHS, the difference is insignificant. The result of this research has also revealed that the difference between well endowed and less endowed SHS in terms of admission requirements is not real but just a perception. However, the level of access to SHS opened to JHS graduates differ according to whether the school is a unisex or mixed sex institution. It was also revealed that access to SHS was influenced by the choice of programme. In the same vein the governing authority of the schools also impacted on the level of access to SHS.

\section{Recommendations}

It is recommended that everything possible should be done to ensure equity in access to SHS. Now that it is clear that the campaign launched for girl child education has made the right impact, the focus of that policy should change to the promotion of equal access to education.

It is further recommended that all the SHS should pay equal attention to disciplinary issues since that is the basis for the bias for the choice of unisex institutions at the expense of mixed schools. There is the need to encourage academic counseling geared towards sensitizing pupils to the importance of every programme offered at SHS.

Finally, it is important to ensure that all SHSs are made equally attractive irrespective of the governing authority of the schools.

\section{References}

Adams, J.S. 1963. Towards An Understanding of Inequality. Journal of Abnormal and Normal Social Psychology 67, 422436.

Allen, R. S. and White, C. S. 2002. Equity sensitivity theory: a test of responses to two types of under-reward situations. Journal of Managerial Issues 14(4), 4435-451.

Asare, K. 2010. JHS - SHS Transition - Any Lesson Yet? Daily Graphic (No. 11314), p.14. 
Bailey, T. Jeong, D. W. and Cho, S. W. (2010). Referral enrolment and completion in developmental education. Sequences in Community Colleges. Economics of Education Review 29, 225.

Bailey, T. 2009. Challenge and Opportunity: Rethinking the role and function of developmental education in community college. New York : Wiley Periodicals, Inc.

Broomer, J. 1999. Research on the urban and rural differences in the chance of Education. Science 24.

Boaduo, N.A. 2005. Secondary Education Provision In Africa: What Form Should It Take In The Twenty-First Century? The African Symposium: An online Journal of the African Educational Research Network 5(4), 1-14. http:// www2. ncsu. edu: 8010/ ncsu/ aern/TAS5.4Boaduo.pdf

Buckel, D. 1984. "The Equal Access Act: What does it mean," Retrieved January 31, 2011 from http://www.glsen.org/

Boocock, S. S. and Predow, K. 1979. Sociological Contributions to Educational EquityTheory. www.eric.ed.gov /ERICWebPortal/custom/portlets/record.

Bregman, J. and Bryner, K. 2003. "Quality of Secondary Education Africa." Paper presented at the ADEA Biennial Meeting Grand Baie, Mauritius. December 3-6, 2003.

Dronkers, J. and Hemsing, W. 1999. Effektivitat offentlichen, kirchlichen und privaten Gymnasialunterrichts. Bildungsund Sozialisationeffekekte in nordrteinwestfalischen Gymnasien. Zeitscharift fur Erziehungswissenschaft, 2, $247-$ 261.

Hoffer, T. B. 1998. Social Background and Achievement in Public and Catholic High Schools. Social Psychology of Education 2, 7-23.

Hooker, M. 2009. Freedom of Education: The Dutch Political Battle for State Funding of all Schools both Public and Private (1801-1920). ISBN 1440493421.

Lathrop, I. T. and Kieffer, T. J. 1959. College achievements of public versus private high school graduates. Berlin : Clearing House.

Lewin, K. M. 2007. Expanded Access to Secondary Schooling in Sub-Saharan Africa:Key Planning and Finance Issues. Research Monograph, 8, 33-35.

Karabel, J. 2006. The Chosen. New York: Mariner Books.

Kendall, J. S., and Marzano, R. J. 1996. Content knowledge: A compendium of standards and benchmarks. for K-12 education. Aurora, CO: Mid-Continent Regional Educational Laboratory.

Madu, B. N. 2010. Perceived Societal Expectations of boys and girls on the Learning of English as a Second Language and How they affect their performance. Gender and Behavior 8, no.1: 2886-2902.

McAthur, C. 1954. Personalities of public and private school boys. Havard : Education Revelation.

National Centre for Research on Evaluation, Standards and Students Testing 1999.

Ndong-Jatta, A. 2006. The Challenges in Secondary Education in Africa and the role of Development Agencies. NGOs and Teacher Unions Seminar of the Norwegian Post-Primary Education Fund for Africa.

Nunan. D. 1992. Research Methods in Language Learning. New York: Cambridge University Press.

OECD (2001a). Education Policy Analysis. Paris: OECD.

Osei-Mensah, P. (2011, Dec. 12). GES should monitor schools for quality education. Daily Graphic (No. 18714 ), p.19.

Roemer, J. 1995. "Equality and Responsibility." Boston Review, April-May issue, 3-7.

Roemer, J. 1998. Equality of Opportunity. Cambridge: Cambridge University Press.

Seltzer, C.C. 1948. "Academic Success in College of Public and Private School Students." Journal of Psychology 25(4), 419-431.

The Dakar Framework for Action 2000. In The Challenges in Secondary Education in Africa and the role of Development Agencie. NGOs and Teacher Unions Seminar of the Norwegian Post-Primary Education Fund for Africa.

The World Bank 2005. Expanding Opportunities and Building Competencies for Young People: A New Agenda for Secondary Education. Washington DC: The World Bank.

UNICEF Malawi/2008 Progress for Children: Achieving the MDGs with Equity. Africa Review 2(9),44-56. 
